\title{
Potential carbon loss from Scottish peatlands under climate change
}

\author{
Anna Ferretto $^{1,2}$ (D) $\cdot$ Rob Brooker $^{2} \cdot$ Matt Aitkenhead $^{2} \cdot$ Robin Matthews $^{2} \cdot$ Pete Smith $^{1}$
}

Received: 3 April 2019 / Accepted: 28 July 2019 / Published online: 10 August 2019

(C) The Author(s) 2019

\begin{abstract}
The Scottish Government is committed to reduce carbon emissions by $80 \%$ by 2050 (compared to a 1990-1995 baseline). Peatlands have been recognised as a key environment for the carbon balance as they sequester and store great quantities of carbon, but they also have the potential to release it. In Scotland, peatlands cover more than $20 \%$ of the surface (more than $90 \%$ of which is blanket bog) and store more than $2500 \mathrm{Mt}$ of carbon. Blanket bogs are very climate reliant, and as a consequence of climate change, many areas in Scotland may not be able to support peatlands in the near future. In this study, two bioclimatic envelope models (Linsday Modified model and Blanket Bog Tree model) have been used to obtain a first estimate of how the distribution of blanket bogs in Scotland could vary according to climate change in the 2050s and in the 2080s. The potential losses of carbon arising from climate change have then been calculated. Results showed that in 2050, more than half of the carbon currently stored in Scottish blanket bogs will be at risk of loss. This is 4.4-6.6 times the amount of carbon emitted in 2016 from all the sectors in Scotland and, if emissions from peatland occur and are taken into account, it will greatly hamper efforts to meet emission reduction targets set out in the Climate Change (Scotland) Act of 2009.
\end{abstract}

Keywords Climate change $\cdot$ Peatlands $\cdot$ Scotland $\cdot$ Carbon stock $\cdot$ Bioclimatic envelope models

\section{Introduction}

With its Climate Change Act (Climate Change (Scotland) Act 2009), the Scottish Government put in place the ambitious goal of an $80 \%$ reduction in carbon (and other greenhouse gas) emissions by 2050 compared to the 1990-1995 baseline, with proposals to increase the ambition of the 2050 target to $90 \%$ of baseline emissions currently under consultation. The Climate Change Plan (Scottish Government, 2018a) sets the yearly targets and the actions needed to reach them. Amongst these actions, improved land management is considered, with the aim of making the land use sector increasingly act as a net

Editorial Responsibility: Wolfgang Cramer

Electronic supplementary material The online version of this article (https://doi.org/10.1007/s10113-019-01550-3) contains supplementary material, which is available to authorized users.

Anna Ferretto

a.ferretto@abdn.ac.uk

1 School of Biological Sciences, University of Aberdeen, 23 St Machar Drive, Aberdeen AB24 3UU, UK

2 The James Hutton Institute, Craigiebuckler, Aberdeen AB15 8QH, UK carbon sink. Because of their ability to store large amounts of carbon, to actively sequester carbon when functioning properly, and because of their wide extent in Scotland, peatlands are explicitly included in the Climate Change Plan.

Peatlands, as defined by the Soil Survey of Scotland, are soils with an organic layer deeper than $50 \mathrm{~cm}$ and with an organic matter content of over 60\% (Chapman et al. 2009). They cover around 1.8 million ha in Scotland (more than 20\% of the land area) (Bruneau and Johnson, 2014). Carbon storage is one of the most important ecosystem services provided by peatland, with a current estimated stock to a depth of $2 \mathrm{~m}$ of $1620 \pm 70 \mathrm{Mt} C$ in Scotland (Chapman et al. 2009).

The rate of carbon sequestration can vary according to many factors including vegetation, topography and climate, which influence the rates of primary production and litter decay and can also vary over time (Byrne et al. 2004; Beylea and Malmer 2004). Clymo et al. (1998) give a range of carbon accumulation rates for northern peatland of 13-21 $\mathrm{g} \mathrm{C} \mathrm{m}^{-2}$ year $^{-1}$ (48-77 g $\mathrm{CO}_{2} \mathrm{~m}^{-2}$ year $^{-1}$ ). Other studies show results in the same range: Yu et al. (2009) calculated a mean rate of carbon sequestration of $18 \mathrm{~g} \mathrm{C} \mathrm{m}^{-1}$ year $^{-1}$ for northern peatland, while Ratcliffe et al. (2018) extrapolated the value of $16.3 \mathrm{~g} \mathrm{C} \mathrm{m}^{-1}$ year $^{-1}$ from peat cores recently sampled in the Flow Country, the widest Scottish (and European) blanket bog extension. 
But, degraded peatland can also act as a source of greenhouse gas emissions: Recent estimates suggest that carbon losses from degraded peatlands in Scotland release $6 \mathrm{Mt}$ $\mathrm{CO}_{2} \mathrm{e}$ per year (Scottish Government 2018a). Many peatland restoration projects have been carried out or have been planned for the coming decades, with the final goal of restoring 250,000 ha (roughly $14 \%$ of the current area) of peatlands by 2030 (Scottish Government, 2018a).

What appears not to be explicitly considered is that climate change might make it more difficult to apply and maintain this plan. In fact, peatlands require certain climatic conditions that in the coming decades might no longer be satisfied everywhere in Scotland where peats currently occur.

The main condition needed for peatland to form is a waterlogged surface and cool temperatures, where the decomposition rate of the dead plant material is very slow because of a lack of oxygen (Lindsay et al. 2014). This allows peat to accumulate and to create new layers in which carbon is stored (Lindsay et al. 2014). But, with the predicted increase of temperature and change in rainfall patterns due to climate change, the suitable area for peatlands might at best change location or at worst be reduced. UKCP09 climate projections forecast warmer and wetter winters and warmer and drier summers (Jenkins et al. 2009), which might not allow a waterlogged environment to be maintained throughout the year and might therefore compromise the entire process of peat formation.

Because of the potential threat to peatlands from climate change, the main aim of this work is to investigate how climate change can impact the extent of peatlands in Scotland and how this could affect the amount of carbon stored within them.

Losing part of this carbon stock would jeopardise Scottish commitments on emission reductions: Carbon losses from peatland could be larger than emissions from other sectors (House et al. 2010). The preservation of this environment should therefore be considered as a priority in Scottish policies, but preservation and restoration have to be done while also considering the potential impact that a changing climate will have on them so that restoration efforts can be focussed on peatlands that will remain viable under future climates (Artz et al. 2014).

The vulnerability of northern peatlands (and in particular of blanket bog) to climate change has already been explored by Clark et al. (2010) applying different statistical bioclimatic envelope models to the UK. Envelope models are statistical models used to define the environmental space where a habitat or a species can be present (Guisan and Zimmermann 2000). One of the main limitations of such models is that they are static, which means that they do not consider eventual feedbacks and, also, they do not take into account the possibility of adaptation of peatland vegetation to the new climatic condition. Keeping in mind these limitations, and considering the uncertainties which stem from this, at a national scale, they can still give a first estimate of how climate change can affect habitat extent. They also represent a useful tool to inform policies, indicating where best to focus restoration efforts.

Bioclimatic envelope models are particularly suitable for predicting the distribution of blanket bogs, because this type of peatland is strongly (and mainly) influenced by climate (Heathwaite 1993). Blanket bogs are ombrotrophic peatlands, which means that they are fed only by rainfall (in contrast to minerotrophic peatlands, which rely also on groundwater), and they need a cold and very wet climate to remain active, i.e. to keep forming peat (JNCC, n.d.). Here, we focus on models of blanket bogs which are taken as representative of peatland in general as blanket bogs constitute more than $90 \%$ of the total extent of peatlands in Scotland (Bruneau and Johnson, 2014).

In this study, we selected, from amongst the models used by Clark et al. (2010), those that best describe the distribution of blanket bog in Scotland. We then ran them using the UKCP09 climate projections to estimate the future extent of blanket bogs in Scotland. Finally, by combining this estimate of future distribution with data on current carbon stocks, we calculated how much carbon could potentially be lost from blanket bogs as a consequence of the reduction of their extent.

\section{Materials and methods}

\section{Overall method}

To estimate the threat from peatland loss to stocks of stored carbon, we combined data from several sources because different information was needed (climate data, blanket bog distribution and carbon currently stored in blanket bogs). The future extent of blanket bogs in Scotland was estimated using two models (Lindsay Modified model and Blanket Bog Tree model (Clark et al. 2010), hereafter referred to as LM and BBOG TREE, respectively). These models use different combinations of climate variables to predict the presence/absence of blanket bogs according to their climate constraints. The maps obtained of blanket bog distribution under future climate scenarios (driven by different emissions levels) were then overlaid with maps of the current carbon stock stored in blanket bogs. This allows us to estimate how much carbon will still be incorporated in blanket bog soil in the 2050s and 2080s, given projected changes in the distributions of bogs. The future carbon stock was modelled for climate change under different emission scenarios: low, medium and high (UKCP09 2009; Nakicenovic et al. 2000).

\section{Statistical bioclimatic envelope models}

To select a model suitable for predicting future distributions of bogs under climate change, ten of the models used by Clark et al. (2010) were tested with baseline climate data for the period 1961-1990 (see Online Resource 1), comparing the outputs on peatland presence or absence of the models with data on the 
current distribution of blanket bog in Scotland. Data from the Carbon and Peatland map 2016 (1:25,000) (SNH, 2016) were used to identify the current distribution of blanket bogs in Scotland. In particular, polygons of 'blanket bog/peat vegetation' were selected from the primary vegetation classes in the Land Cover of Scotland 88 dataset ('The Land Cover of Scotland' 1988). The ten models were compared for their accuracy and sensitivity. Accuracy is calculated by dividing the number of $5 \times 5 \mathrm{~km}$ cells that correctly predict presence (when in the cell there is at least some bog) or absence (when in the cell there is no bog at all) of blanket bog by the total number of cells. Sensitivity was calculated by dividing the number of $5 \times 5 \mathrm{~km}$ cells that correctly predict the presence of blanket bog by the number of cells in which there was actually blanket bog. With this approach, the models detect in which cells there are the climatic conditions that would allow bogs to exist, that is if there is the possibility (in climatic terms) of having bog presence. So, if in the cell, there is some bog and the models show that there can be, this is defined as a positive result, regardless of the coverage of the bog within the cell.

From the ten models tested, BBOG TREE and LM were selected to estimate the future distribution of blanket bogs, because they showed the best performance in Scotland (high accuracy and high sensitivity) in the baseline period 19611990. They were both used because they give two different but equally possible outcomes, considering different sets of variables. Other models were excluded because either they were not as accurate/sensitive for predicting peatland extent in Scotland, or they were built using the same variables used in BBOG TREE or LM, but with poorer performance.

The equations for the BBOG TREE (1) and LM (2) models are as follows:

\section{BBOG TREE:}

Probability of Blanket Peat $=1$ if $T_{\max }$

$$
<17.4^{\circ} \mathrm{C} \text { and } \mathrm{TMI}>0.41
$$

or

$T_{\max }>17.4^{\circ} \mathrm{C}$ and AAMWD $<-28.6 \mathrm{~mm}$

where

$T_{\max }=$ maximum yearly temperature

TMI = Thornthwaite-Mather Moisture Index (which is a measure of the annual balance between precipitation and potential evapotranspiration)

AAMWD = annual accumulated monthly water deficit (which, in contrast to TMI, accounts for the seasonality in the balance between precipitation and potential evapotranspiration)

$L M$ :

Probability of Blanket Peat $=1$ if $P$

$>1000 \mathrm{~mm}$ and $T_{\mathrm{m}}<15^{\circ} \mathrm{C}$ where

$P=$ total yearly precipitation

$T_{\mathrm{m}}=$ maximum monthly mean temperature

MetOffice monthly gridded Climate Data were used for the baseline period 1961-1990 (5 ×5 km resolution) (Met Office 2018a). Datasets considered were mean and maximum temperature $\left({ }^{\circ} \mathrm{C}\right)$, mean precipitation $(\mathrm{mm})$ and days with rainfall $>$ $1 \mathrm{~mm}$. From these datasets, other climate variables were extracted or derived: maximum monthly mean temperature, total yearly precipitation, monthly and yearly potential evapotranspiration (PET), Thornthwaite-Mather Moisture Index (TMI), and annual accumulated monthly water deficit (AAMWD). (For PET, TMI and AAMWD equations, see Online Resource 2). Compared to TMI, AAMWD accounts for the seasonality in the balance between $\mathrm{P}$ and PET and can hence provide a seasonally nuanced measure (Gignac et al. 2000).

UKCP09 Spatially Coherent Projections $(25 \times 25 \mathrm{~km}$ resolution) were used for the future projections of the climate variables (Met Office 2018b). Data for low, medium and high emission scenarios in the 2050s and in the 2080s were taken into account. These scenarios model the greenhouse gasses emission according to different demographic and socioeconomic development and technological change. The main difference amongst the three scenarios is due to how much the society will rely on fossil fuels in the future: The high emission scenario is based on a heavy reliance on fossil fuels, the low emission scenario is based on a departure from fossil fuels and the medium scenario still involves the use of fossil fuels but with a partial substitution with renewable energy. Datasets used were mean and maximum temperature $\left({ }^{\circ} \mathrm{C}\right)$ and mean precipitation $(\mathrm{mm})$.

For BBOG TREE and LM models, the distribution of blanket bog under threat from future climate change in Scotland was then estimated with the UKCP09 climate projections for three different emissions scenarios (low, medium and high) and for two different time periods (2050s and 2080s) with a resolution of $25 \times 25 \mathrm{~km}$.

\section{Carbon stock}

There is considerable variation in current approaches to calculating the carbon stock currently stored in Scottish peatlands. Many attempts have been made to estimate it, and the extremes of the estimated range are $600 \mathrm{Mt} \mathrm{C}$ (Robertson 1971) and 16,412 Mt C (Howard et al. 1995). The main sources of uncertainty are peat depth and bulk density, for which there are not enough values measured from field survey to provide a robust statistical overview of Scotland's peats, and the extent of peatland, which varies according to the definition used to map it. The most recent estimates are closer to each other: $813 \mathrm{Mt} \mathrm{C}$ for the first meter of depth according to Aitkenhead and Coull (2016) and $1620 \mathrm{Mt} \mathrm{C}$ for the first two meters of depth according to Chapman et al. (2009). 
In this work, we used carbon stock data obtained with a Neural Network approach (NN), which considers soil, topographic and climatic parameters, and combines them with loss on ignition, bulk density and peat depth data. These data (Aitkenhead, in prep) are the update of Aitkenhead and Coull (2016), and they consider the whole peat depth (instead of just the first meter). The resolution of this dataset is $100 \times 100 \mathrm{~m}$.

The original carbon stock map considers carbon stored in peat plus the carbon stored in organic topsoil of less than 50$\mathrm{cm}$ depth (which is not technically peatland according to the definition given by the soil survey of Scotland). In order to have the carbon stock stored only in blanket bogs, this map was filtered with the blanket bog/peat vegetation layer previously obtained. The values of each $100 \times 100-\mathrm{m}$ pixel were summed, and the value of the current carbon stock stored in blanket bogs on Scotland was calculated.

\section{Future carbon estimates}

To estimate future carbon stock in Scottish blanket bogs, the extent of bog predicted not to be under threat from climate change with the BBOG TREE and LM models was overlain on the map of current carbon stock. The layers showing the predicted distribution of blanket bog not being under threat from climate change in the future were first downscaled to a resolution of $100 \times 100 \mathrm{~m}$ to get the same resolution as the carbon stock layer. The carbon content of those $100 \times 100-\mathrm{m}$ pixels where the blanket bog is projected to remain free from climate change threat under future climate scenarios was summed, and a total stock for the whole of Scotland was calculated.

The same procedure was followed for each model (BBOG TREE and LM), each emission scenario (low, medium, high) and each time period (2050s and 2080s), and a total of 12 maps and 12 possible values of carbon stock were obtained.

\section{Results}

\section{Bioclimatic envelope model selection}

The models with the best performance in Scotland for the baseline period 1961-1990 were BBOG TREE and LM, both with a good accuracy ( 0.78 and 0.77$)$ and a good sensitivity (0.79 and 0.83) (Table 1).

Table 1 also shows the true and false results obtained for each model and used to calculate accuracy and sensitivity: true positives/true negatives are those pixels for which the model correctly predicted the current presence/absence of blanket bog; false positives/false negatives are those pixels where the model fails because either it predicts blanket bog where there is none, or it does not capture blanket bog where it is present. Accuracy was calculated by dividing the true results (both positives and negatives) by the total number of cells; sensitivity was calculated by dividing the true positives by the sum of true positives and false negatives.

Linsday (L) (see equation in Online resource 1) also showed good accuracy and sensitivity but was excluded because LM is its simplification (it considers the same variables and thresholds, apart from rainy days) and performs slightly better.

A graphic display of BBOG TREE and LM results for Scotland is given in Fig. 1: The maps show how well the models reflect the real distribution of blanket bog. Overall, the two models give similar results, with the majority of false results in the north east (false negatives-light green) and in the south (false positives-light blue) of the country. The main difference is in the south, where BBOG TREE gives more false negative and LM gives more false positives.

\section{Blanket bog distribution projections}

We used the BBOG TREE and LM models to test the potential future distribution of blanket bog in Scotland for three different scenarios (low, medium and high emission) and for two different time periods (2050s and 2080s).

As shown in Figs. 2 and 3 respectively, for both the BBOG TREE and LM models, a progressive increase in the areas of blanket bog at risk from climate change is predicted. There is not a great difference amongst the three emission scenarios in 2050 for either model, but in 2080, the area of blanket bog under threat is much more accentuated in the high emission scenario, especially for the LM model, where the reduction is very drastic, with only small areas of blanket bog in the Cairngorms, very small areas in the Highlands and part of the Shetland not being threatened by climate change.

Regarding where this threat from climate change occurs, the two models show some differences: While overall, the BBOG TREE model predicts a great advance in climate threat towards the east, according to the LM model, the southern blanket bogs will be most impacted by the climate change. This trend in the LM model is evident mostly for 2050 (in each scenario), while in 2080, the area of blanket bogs under threat will also include some eastern parts of the country and, in the high emission scenario, almost the whole current extent.

What is particularly evident is the loss of a huge quantity of blanket bog in Caithness and Sutherland: This area is currently almost completely covered by blanket bog, which is projected to be under threat of loss already in 2050 according to the BBOG TREE model (for any emission scenario), and in 2080 according to LM model for the high emissions scenario. It is, however, important to take into account that part of the loss in Caithness is due to a weakness in the models (both BBOG TREE and LM are not able to detect the most eastern part of blanket bog in Caithness, where false negatives occur compared to the distribution of blanket bog with the baseline data-Fig. 1). 
Table 1 Results from the evaluation of the 10 bioclimatic models for the baseline period 1961-1990 against the current blanket bog distribution

\begin{tabular}{|c|c|c|c|c|c|c|}
\hline Model & True positives (pixels) & True negatives (pixels) & False positives (pixels) & False negatives (pixels) & Accuracy & Sensitivity \\
\hline P50 & 1398 & 681 & 184 & 930 & 0.60 & 0.65 \\
\hline P65 & 712 & 773 & 92 & 1616 & 0.47 & 0.31 \\
\hline H-GLM & 1318 & 658 & 207 & 1010 & 0.62 & 0.57 \\
\hline $\mathrm{L}$ & 1843 & 586 & 279 & 485 & 0.76 & 0.79 \\
\hline L-GLM & 996 & 776 & 89 & 1332 & 0.55 & 0.43 \\
\hline LM & 1927 & 538 & 327 & 401 & 0.77 & 0.83 \\
\hline LM-GLM & 904 & & 85 & 1424 & 0.53 & 0.39 \\
\hline BBOG TREE & 1884 & 638 & 227 & 484 & 0.78 & 0.79 \\
\hline BBOG & 1418 & 669 & 196 & 910 & 0.65 & 0.61 \\
\hline BBOG-GLM & 794 & 780 & 85 & 1534 & 0.49 & 0.34 \\
\hline
\end{tabular}

In the Orkneys, the BBOG TREE model projects that all blanket bog will be at threat under the high emission scenario in 2050 and the medium and high scenario in 2080, while the LM model projects that this occurs only in 2080, and only in the high emission scenario.

The BBOG TREE model also predicts that blanket bog in the Grampians will already be under threat in 2050 and even more so in 2080 (especially according to the high emission scenario, where the area under threat is $100 \%$ ).

In the central belt and in the area to the south of it, the small extent of blanket bog is predicted to be at great threat in 2050 for both the models and all the emission scenarios, and almost all of the area would be under threat in 2080 for any scenario of BBOG TREE model and the entire area would be under threat for the medium and high scenario with the LM model.

The most resilient areas, for both the models, are the Shetlands and the Highlands. In the Shetlands, the blanket bog extent will not be threatened in 2050 in either model or for any emissions scenario, and will undergo a reduction in 2080 only under the high emission scenario (for both BBOG TREE and LM models). Most of the eastern part of The Highlands is projected to be under threat in 2050 according to BBOG MODEL, but the additional area under threat is then small in 2080. The LM model does not predict any threat under the low and medium emission scenarios in 2050, and a small area under threat for the high emission scenario in 2050 and for the low and medium scenarios in 2080. However, for the high emission scenario in 2080, almost all of the blanket bog will be under threat, including in the Highlands.

\section{Carbon stock projections}

By overlaying the projections of the future blanket bog extent obtained with BBOG TREE and LM models with the carbon stock map, we obtained the cells where blanket bog will not be under threat. Then, by summing the values of carbon stock of
Fig. 1 Results from the overlap of BBOG TREE (a) and LM model (b) for the baseline period 19611990 with the Carbon and Peat map 2016 (5 $\times 5-\mathrm{km}$ resolution). True positives (TP) and true negatives (TN) are shown in blue and in dark green; false positives (FP) and false negatives $(\mathrm{FN})$ are shown in light blue and in light green

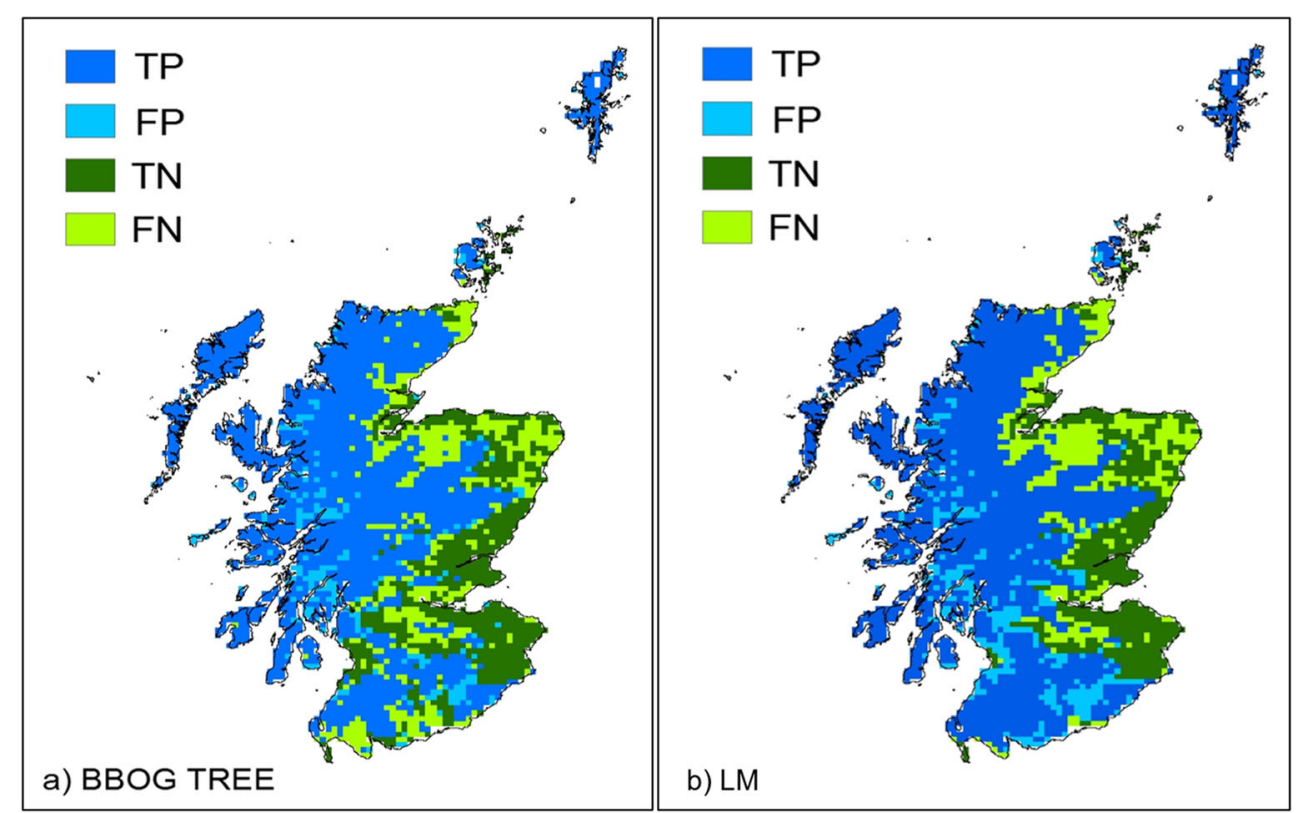


Fig. 2 Future projections of blanket bog according to BBOG TREE model in 2050 for the low (a), medium (b) and high (c) emission scenario and in 2080 for the low (d), medium (e) and high (f) emission scenario. Current blanket bog is shown in red; the future projection is shown in blue a) $2050 \mathrm{~s} \mathrm{low}$
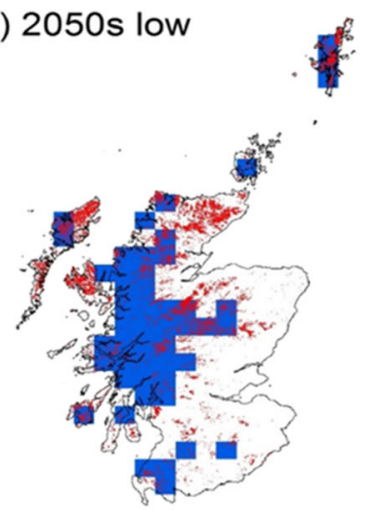

d) $2080 \mathrm{~s} \mathrm{low}$

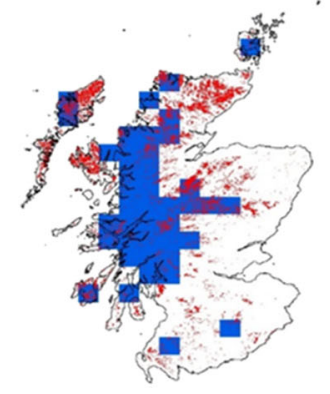

Fig. 3 Future projections of blanket bog according to LM model in 2050 for the low (a), medium (b) and high (c) emission scenario and in 2080 for the low (d), medium (e) and high (f) emission scenario. Current blanket bog is shown in red; the future projection is shown in blue

a) $2050 \mathrm{~s} \mathrm{low}$ b) 2050s medium

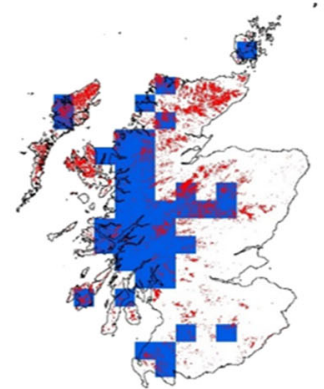

e) 2080s medium

b) $2050 \mathrm{~s}$ medium

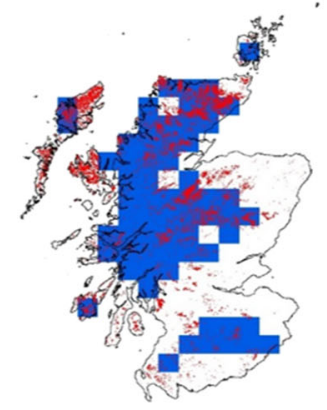

d) $2080 \mathrm{~s} \mathrm{low}$

e) $2080 \mathrm{~s}$ medium

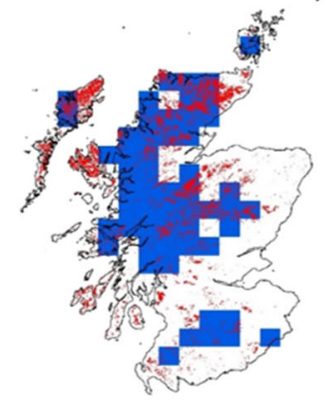

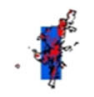
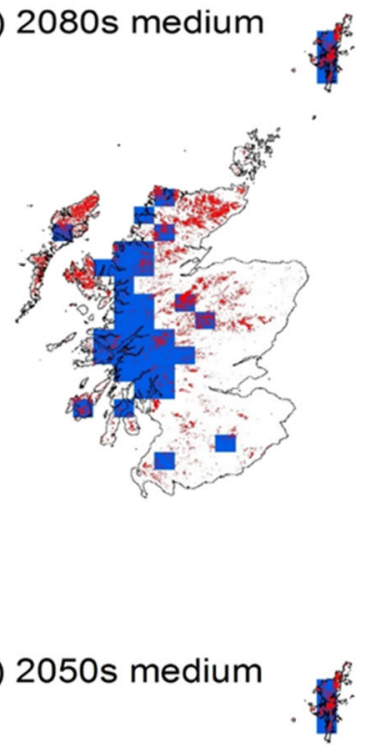

c) 2050s high
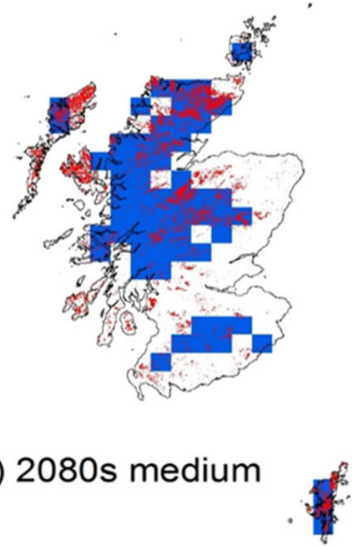

c) $2050 \mathrm{~s} \mathrm{high}$

残

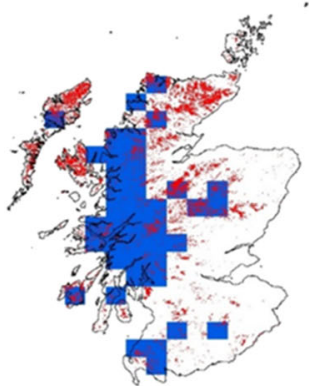

f) $2080 \mathrm{~s} \mathrm{high}$
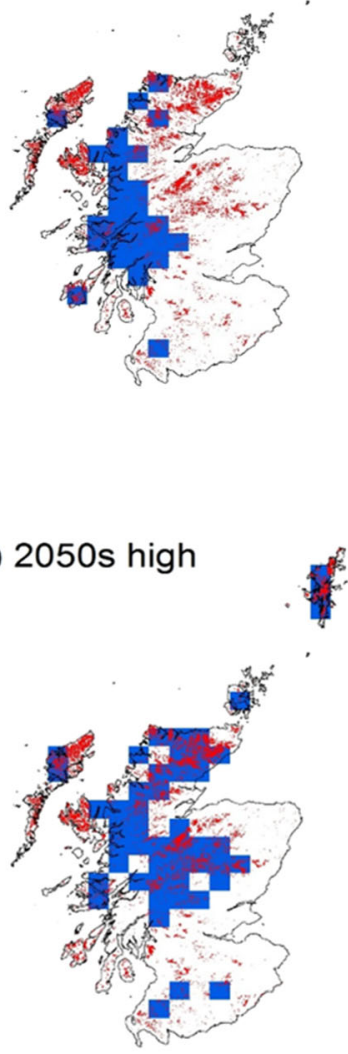

f) $2080 \mathrm{~s} \mathrm{high}$
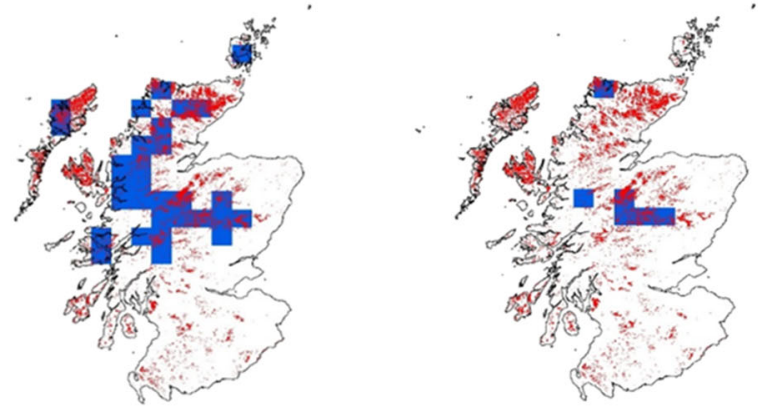
these cells, we obtained the total carbon stock stored in blanket bogs in 2050 and in 2080 (according to the low, medium and high emission scenarios) (Figs. 4 and 5).

The current value of carbon stock in Scottish blanket bogs, obtained by filtering the carbon stock map (which considers all the peat), with the blanket bog/peat vegetation layer, is 2527 Mt C. By subtracting the future estimates of carbon stock to these values, the carbon at risk of loss was obtained for each model, each scenario and each decade.

As shown in Fig. 6, according to both BBOG TREE and LM model, the amount of carbon stored in Scottish blanket bogs is predicted to be at risk of drastic decline, with half of the current carbon stock already at risk by the 2050s. If all the carbon at risk were lost, the current carbon stock of $2527 \mathrm{MtC}$ would drop to $1167-1054 \mathrm{Mt} \mathrm{C}$ according to the BBOG TREE model and to $1536-1215 \mathrm{Mt} \mathrm{C}$ according to the LM model. In both the models, the range between the low and the high emission scenario is almost three times greater in 2080 than in 2050. In the BBOG TREE model, this range is $113 \mathrm{Mt}$ $\mathrm{C}$ in 2050 versus $319 \mathrm{Mt} \mathrm{C}$ in 2080; in the LM model, the differences are higher for both the decades but still more accentuated (almost four times) in 2080 compared to 2050 (321 Mt C versus 1197 Mt C).

All the results of this analysis are shown in Table 2, together with the potential net loss of carbon in relation to the current stock of $2527 \mathrm{Mt} \mathrm{C}$. Irrespective of which model is used, the total carbon at risk of loss in 2050 is around $1000 \mathrm{Mt} \mathrm{C}$, even in

Fig. 4 Future projections of carbon stock in blanket bogs in Scotland according to BBOG TREE model in 2050 for the low (a), medium (b) and high (c) emission scenario and in 2080 according to the low (d), medium and high (f) emission scenario the low emissions scenario (991 Mt C according to LM model, $1360 \mathrm{Mt} \mathrm{C}$ according to BBOG TREE model). For the same scenario, in 2080, the values for the two models are similar to 2050 s values (1154 Mt C for LM and $1475 \mathrm{Mt} \mathrm{C}$ for BBOG TREE). If we consider the high emission scenario, the potential loss of carbon in 2050s is, overall, not much greater than in the low emissions scenario (1312 Mt C for LM and $1473 \mathrm{MtC}$ for BBOG TREE), but in 2080, it grows to over $2000 \mathrm{Mt} \mathrm{C}$ (1794 Mt C for BBOG TREE and $2351 \mathrm{Mt} \mathrm{C}$ for LM). Looking at the carbon at risk in the different decades, the difference between the 2050s and the 2080s is much more pronounced in the high emission scenario rather than in the low emission scenario, for both the models. The potential loss of carbon in the 2080s compared to the 2050s is 2.79 times higher in the BBOG TREE model (115 Mt C in the low emission scenario versus $321 \mathrm{Mt} \mathrm{C}$ in the high emission scenario) and 6.4 times higher in the $\mathrm{LM}$ model $(163 \mathrm{Mt} \mathrm{C}$ in the low emission scenario versus $1039 \mathrm{Mt} \mathrm{C}$ in the high emission scenario).

\section{Discussion and conclusion}

This work aimed to assess the potential threat from climate change to the extent of Scottish peatlands and the carbon that they store.

Clark et al. (2010) used an ensemble of ten bioclimatic envelope models to assess the future extent of blanket bog,

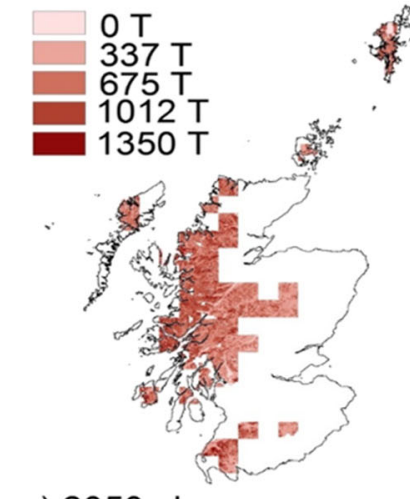

a) $2050 \mathrm{~s} \mathrm{low}$

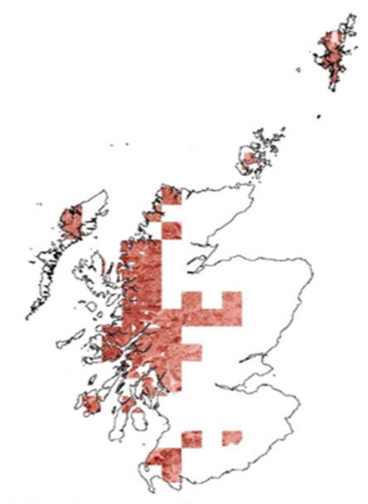

b) $2050 \mathrm{~s}$ medium

c) $2050 \mathrm{~s} \mathrm{high}$
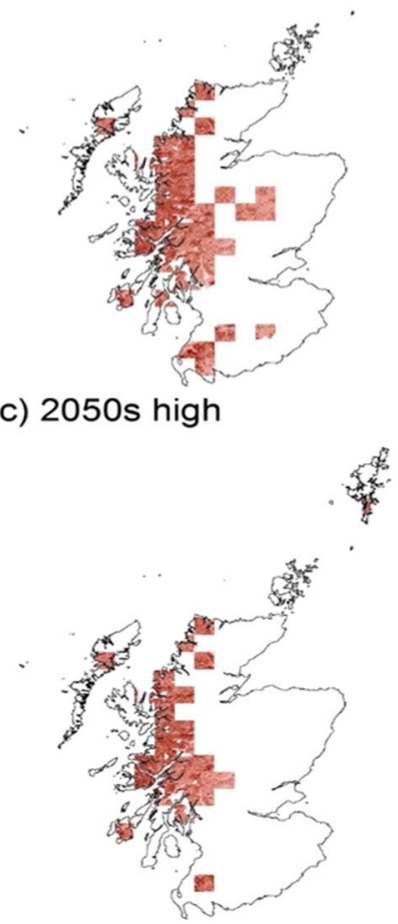

f) $2080 \mathrm{~s} \mathrm{high}$ 
Fig. 5 Future projections of carbon stock in blanket bogs in Scotland according to LM model in 2050 for the low (a), medium (b) and high (c) emission scenario and in 2080 according to the low (d), medium and high (f) emission scenario

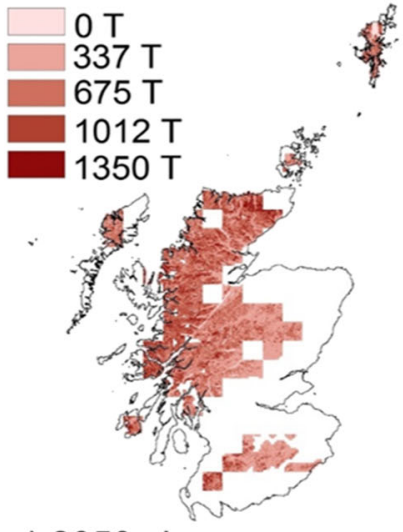

a) $2050 \mathrm{~s} \mathrm{low}$

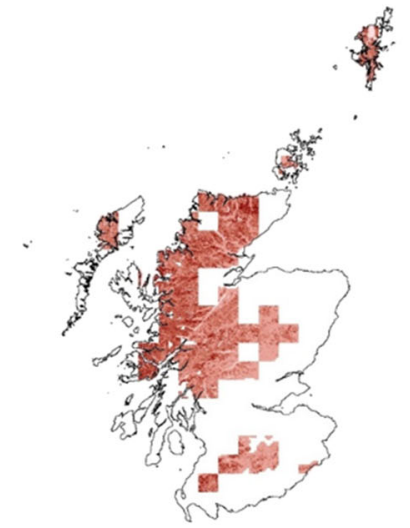

d) $2080 \mathrm{~s} \mathrm{low}$

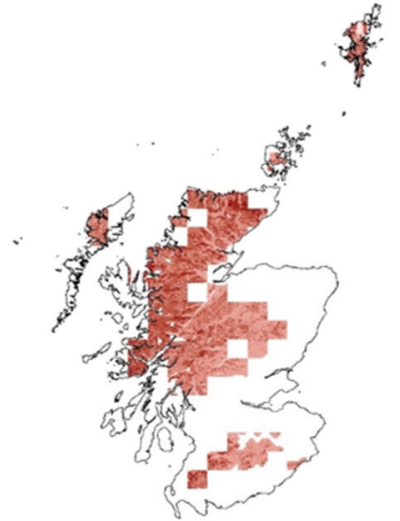

b) $2050 \mathrm{~s}$ medium
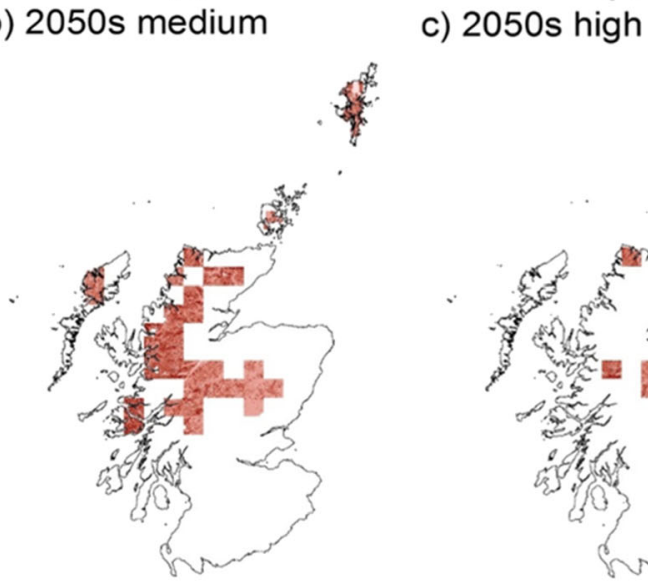

e) $2080 \mathrm{~s}$ medium c) 2050 s high
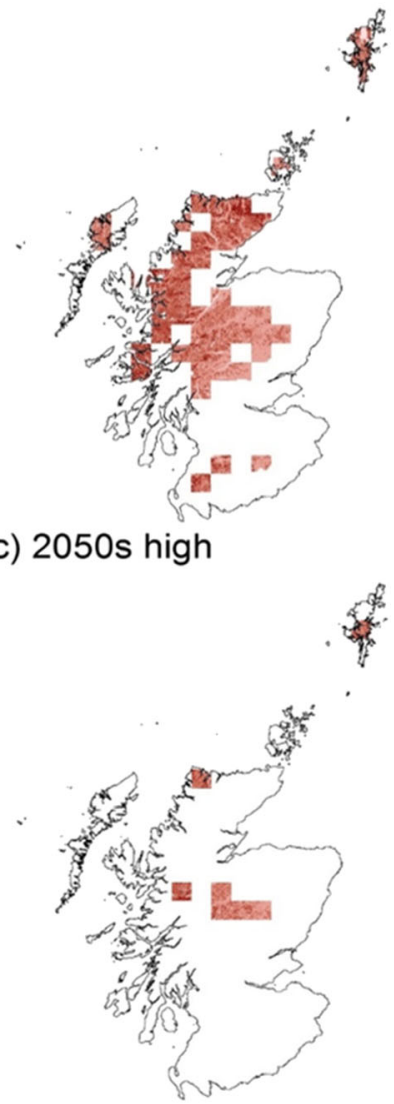

f) $2080 \mathrm{~s} \mathrm{high}$ according to their climatic needs. When calibrated with the baseline period 1961-1990, not all of the models used for the UK proved adequate for application in Scotland. This could be due to the fact that some areas in England are far too warm and dry for blanket bogs, which makes it easier for the models to correctly predict their absence, and this increases their apparent accuracy.

The BBOG TREE and LM models showed high accuracy and sensitivity, and were selected for application to Scotland in the remainder of the analysis. UKCP09 climate projections were used, but patterns of loss of blanket bog in Scotland are similar to those found by Clark et al. (2010) using UKCIP02 climate data. Each model forecasts a similar reduction in blanket bog distribution for all warming scenarios in 2050, but there were greater differences amongst the emission scenarios in 2080. The reason is that the climate projections diverge much more by the 2080 s than by the 2050s. For example, the differences between the range of values of mean monthly precipitation in the high emission scenario and in the low emission scenario are $0.008 \mathrm{~mm}$ and $0.669 \mathrm{~mm}$ in the 2050s and $-0.112 \mathrm{~mm}$ and $2.214 \mathrm{~mm}$ in the $2080 \mathrm{~s}$.

LM and BBOG TREE are based on different variables, and they return two different, but equally plausible predictions. LM is a model mainly based on temperature and precipitation, while BBOG TREE is mainly based on the balance between evaporation and precipitation, which regulates the level of the water table. As already proposed by Clark et al. (2010), this is probably the reason why LM predicts a retreat towards the north and to high altitudes, where there will still be a suitable temperature, while BBOG TREE predicts a retreat towards the more humid west.

Coming to the potential loss of carbon, our results show that in all the emission scenarios and for both the models, in 30-year time, about half of the current carbon stock of Scottish blanket bog is at risk from climate change. The $\sim 1000 \mathrm{Mt}$ of carbon that can potentially be released by blanket bog might prevent Scotland from reaching its emission reduction target if loss of carbon from peatland is accounted for. Converting our values of potential loss of carbon per year into potential $\mathrm{CO}_{2}$ emissions per year, we would have a potential annual emission of 121-180 $\mathrm{Mt} \mathrm{CO}_{2}$ if we consider 2050 or of $71-143 \mathrm{Mt}$ $\mathrm{CO}_{2}$ if we consider 2080. While this represents a small contribution to global $\mathrm{CO}_{2}$ emissions - which were $37 \mathrm{Gt} \mathrm{CO}_{2}$ in 2018 (Le Quèrè et al. 2018) - it represents a significant share of emissions in Scotland. With total emissions of $\mathrm{CO}_{2}$ across all sectors in Scotland in 2016 of $27.3 \mathrm{Mt} \mathrm{CO}_{2}$ (Scottish Government 2018b), the carbon at risk in Scottish peatlands in 2050 represents 4.4-6.6 times total current annual emissions, or 2.6-5.3 times total current annual emissions if lost by 2080 . Not all carbon would be expected to be lost over 

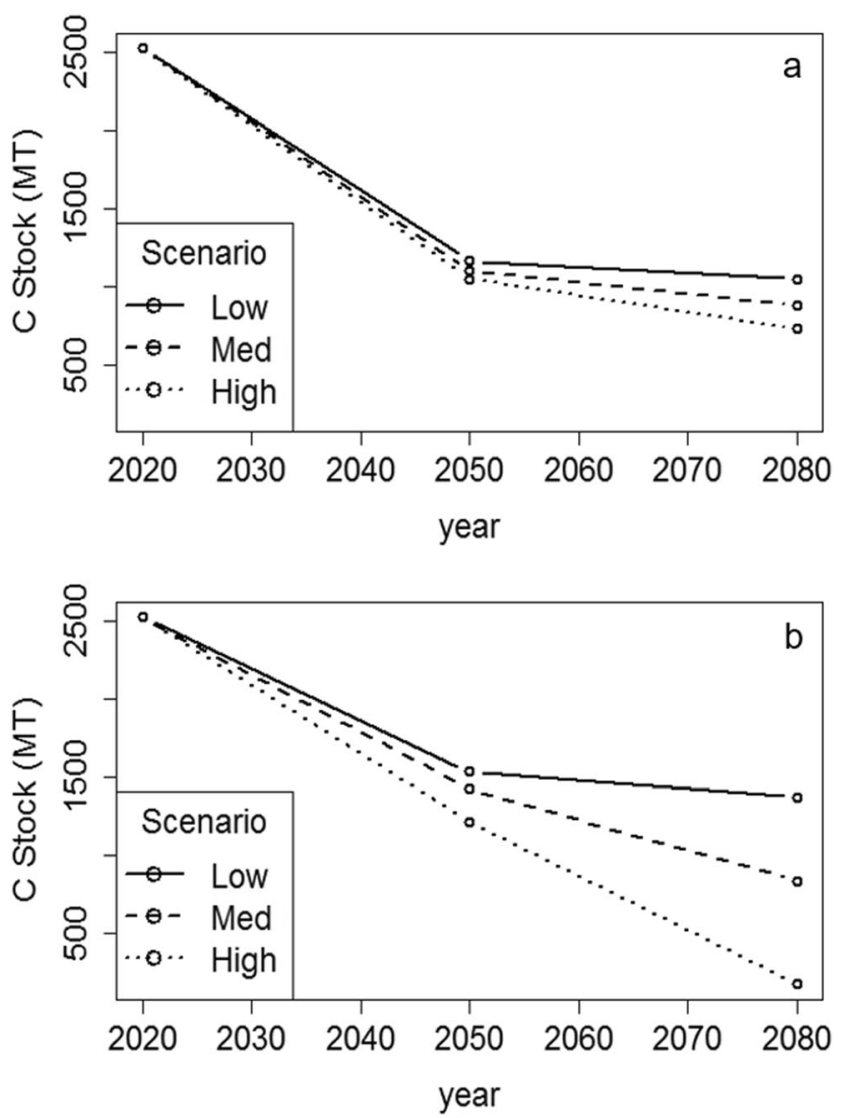

Fig. 6 Trend of carbon stock stored in Scottish blanket bogs according to BBOG TREE (a) and LM models (b)

these time scales, but these numbers indicate the potential scale of the threat to carbon stocks from future climate change, and the potential threat to meeting Scotland's climate change targets.

Hence, there is an urgency to protect those areas that store huge amounts of carbon that are at high risk because of climate change. For example, the Flow Country peatlands of
Caithness and Sutherland are the largest blanket bog extent in Europe and store now $400 \mathrm{Mt} \mathrm{C}$ (Forestry Commission Scotland 2018). According to our results, it will be one of the areas most at risk from climate change. Given also the large quantity of carbon stored, this region should be one of those in which to focus restoration efforts. The same verdict comes from the WISE Peatland choice tool, a tool developed to define areas in Scottish peatlands where, according to 25 different criteria, the major efforts of restoration should be invested (Artz et al. 2012). As discussed by Artz et al. 2013 and by Worrall et al. (2011), whether and in which terms restoration will bring carbon benefits is still an active topic of debate. Many factors make this difficult to estimate, such as a lack of long-term studies, and different peatland conditions before restoration, i.e. whether the peatland is heavily damaged or close to pristine condition. Also, gains in terms of $\mathrm{CO}_{2}$ sequestration could be offset by increased activity of methanogenic bacteria, as a result of the re-established waterlogged (and oxygen poor) conditions, which would lead to higher emissions of $\mathrm{CH}_{4}$ (Waddington et al. 2010). Even considering these uncertainties, the main trend in the literature is that restoration leads, overall, to a reduction of emissions (mainly avoiding further losses), although the time span and the amount of carbon saved show great variation (Artz et al. 2013). The incentives for restoration come mainly from improvements in other sectors like biodiversity and hydrology, but Worrall et al. (2009) modelled the carbon balance in an upland peatland in the UK and found that carbon offsetting could alone pay the costs of these activities.

In particular, measures designed to limit carbon losses as a consequence of a warmer and drier climate have been suggested by Lindsay (2010): the restoration of the acrotelm (the upper peat layer above the average water table level) with a functioning microtopography and vegetation, and a water management scheme aimed to increase the natural hydrological resilience of the peatlands. The findings of this study need
Table 2 Projected carbon stock according to BBOG TREE and LM models and potential losses of carbon from the current value of $2527 \mathrm{Mt} \mathrm{C}$

\begin{tabular}{lllcc}
\hline Model & Scenario & Decade & $\begin{array}{l}\text { Soil C stock in } \\
\text { target year (Mt C) }\end{array}$ & $\begin{array}{l}\text { Total C at risk of loss } \\
\text { from present (Mt C) }\end{array}$ \\
\hline BBOG TREE & Low & $2050 \mathrm{~s}$ & 1167 & 1360 \\
BBOG TREE & Low & $2080 \mathrm{~s}$ & 1052 & 1475 \\
BBOG TREE & Medium & $2050 \mathrm{~s}$ & 1107 & 1420 \\
BBOG TREE & Medium & $2080 \mathrm{~s}$ & 887 & 1640 \\
BBOG TREE & High & $2050 \mathrm{~s}$ & 1054 & 1473 \\
BBOG TREE & High & $2080 \mathrm{~s}$ & 733 & 1794 \\
LM & Low & $2050 \mathrm{~s}$ & 1536 & 991 \\
LM & Low & $2080 \mathrm{~s}$ & 1373 & 1154 \\
LM & Medium & $2050 \mathrm{~s}$ & 1426 & 1101 \\
LM & Medium & $2080 \mathrm{~s}$ & 839 & 1688 \\
LM & High & $2050 \mathrm{~s}$ & 1215 & 1312 \\
LM & High & $2080 \mathrm{~s}$ & 176 & 2351 \\
\hline
\end{tabular}


to be interpreted in light of important limitations. Some uncertainties come from the climate projections, the calculation of the current carbon stock and the bioclimatic models themselves. As underlined also by other authors (Gallego-Sala et al. 2010; Heikkinen et al. 2006), bioclimatic envelope models should be used as a first approximation, being aware of their limits. As previously stated, these models do not consider eventual feedback that could result from a changing climate and they also do not account for an eventual adaptation of blanket bogs. Besides this, it has to be remembered that bioclimatic models define if an area is climatically suitable for a habitat. The fact that an area will no longer be suitable for blanket bogs does not imply that all the carbon stored in their soil will be immediately released. This is why we refer to it as 'carbon at risk of loss' or 'potential carbon loss' and not as 'carbon loss', since the timescale of the carbon loss is uncertain.

Nevertheless, the very large quantity of carbon that we found to be at risk of loss, and the very large contribution of these potential emissions to total current emissions from every sector in Scotland, suggests that this issue needs to be taken into urgent consideration. Besides this, we have not considered other indirect impacts of climate change. For example, climate change can also increase peat erosion (Heathwaite 1993; Li et al. 2016), putting further pressure on those blanket bogs that are situated in locations where the climate is no longer suitable to support their continued longterm existence. Another indirect effect is the increased risk of fire both in number and in severity. Fire is a common phenomenon in peatland, and it usually involves the surface layer. But, with drier conditions, fire can deepen and touch carbon that has been stored for millennia (Turetsky et al. 2015).

In this study, we focus only on the carbon storage implications of changing peatland extent under future climate change. However, peatlands offer a wide spectrum of other ecosystem services, and future research will examine the impact of the potential changing peatland extent on biodiversity (and the services that it provides), fresh water availability and nitrogen losses.

Funding This work was supported by a Studentship from the Macaulay Development Trust.

\section{Compliance with ethical standards}

Conflict of interest The authors declare that they have no conflict of interest.

Open Access This article is distributed under the terms of the Creative Commons Attribution 4.0 International License (http:// creativecommons.org/licenses/by/4.0/), which permits unrestricted use, distribution, and reproduction in any medium, provided you give appropriate credit to the original author(s) and the source, provide a link to the Creative Commons license, and indicate if changes were made.

\section{References}

Aitkenhead MJ, Coull MC (2016) Mapping soil carbon stocks across Scotland using a neural network model. Geoderma 262:187-198. https://doi.org/10.1016/J.GEODERMA.2015.08.034

Artz RRE, Chapman SJ, Donnelly D, \& Matthews RB (2012) Potential abatement from peatland restoration. Policy Briefing to the Scottish Government. Centre of Expertise on Climate Change. pp. 8

Artz RRE, Donnelly D, Aitkenhead M, Balana B, \& Chapman S (2013) WISE peatland choices - a decision support tool for peatland restoration in Scotland. The James Hutton Institute, 16 pp. Version 2, September 2014

Artz RRE, Donnelly D, Andersen R, Mitchell R, Chapman SJ, Smith J, Smith P, Cummins R, Balana B, Cuthbert A (2014) Managing and restoring blanket bog to benefit biodiversity and carbon balance - a scoping study. vol. Report No. 562, Scottish Natural Heritage, UK

Beylea RL, Malmer N (2004) Carbon sequestration in peatland: patterns and mechanisms of response to climate change. Glob Chang Biol 10:1043-1052. https://doi.org/10.1111/j.1365-2486.2004.00783.x

Bruneau PMC, Johnson SM (2014) Scotland's Peatland-Definitions \& Information Resources; Scottish Natural Heritage Commissioned Report No. 701; Scottish Natural Heritage: Edinburgh, UK

Byrne KA, Chojnicki B, Christensen TR, Drösler M, Freibauer A, Friborg T, Frolking S, Lindroth A, Mailhammer J, Malmer N, Selin P, Turunen J, Valentini R, Zetterberg L (2004) EU peatlands: Current carbon stocks and trace gas fluxes, Carbo-Europe-GHG, Concerted Action-Synthesis of the European Greenhouse Gas Budget, Report, 4, 2004

Chapman SJ, Bell J, Donnelly D, Lilly A (2009) Carbon stocks in Scottish peatlands. Soil Use Manag 25(2):105-112. https://doi.org/ 10.1111/j.1475-2743.2009.00219.x

Clark JM, Gallego-Sala AV, Allott TEH, Chapman SJ, Farewell T, Freeman C, House JI, Orr HG, Prentice IC, Smith P (2010) Assessing the vulnerability of blanket peat to climate change using an ensemble of statistical bioclimatic envelope models. Clim Res 45(1):131-150. https://doi.org/10.3354/cr00929

Climate Change (Scotland) Act 2009. Statute Law Database. Retrieved from http://www.legislation.gov.uk/asp/2009/12/contents

Clymo RS, Turunen J, Tolonen K (1998) Carbon accumulation in peatland. Oikos 81(2):368-388. https://doi.org/10.2307/3547057

Gallego-Sala A, Clark J, House J, Orr H, Prentice I, Smith P, Farewell T, Chapman S (2010) Bioclimatic envelope model of climate change impacts on blanket peatland distribution in Great Britain. Clim Res 45:151-162. https://doi.org/10.3354/cr00911

Gignac LD, Halsey LA, Vitt DH (2000) A bioclimatic model for the distribution of sphagnum-dominated peatlands in North America under present climatic conditions. J Biogeogr 27(5):1139-1151. https://doi.org/10.1046/j.1365-2699.2000.00458.x

Guisan A, Zimmermann NE (2000) Predictive habitat distribution models in ecology. Ecol Model 135(2-3):147-186. https://doi.org/10.1016/ S0304-3800(00)00354-9

Heathwaite AL (1993) Disappearing peat-regenerating peat? The impact of climate Change on British peatlands. Geogr J 159(2):203-208. https://doi.org/10.2307/345141

Heikkinen RK, Luoto M, Araújo MB, Virkkala R, Thuiller W, Sykes MT (2006) Methods and uncertainities in bioclimatic envelope modelling under climate change. Prog Phys Geogr 30(6):751-777. https:// doi.org/10.1177/0309133306071957

Hossell JE, Briggs B, Hepburn IR (2000) Climate Change and UK nature conservation: a review of the impact of climate change on UK species and habitat conservation policy. In: Department of the Environment, Transport and the Regions. UKCIP Technical Report, Oxford 
House JI, Orr HG, Clark JM, Gallego-Sala AV, Freeman C, Prentice C, Smith P (2010) Climate change and the British uplands: evidence for decision-making. Clim Res 45:3-12. https://doi.org/10.3354/ cr00982

Howard PJA, Loveland PJ, Bradley RI, Dry FT, Howard DM, Howard DC (1995) The carbon content of soil and its geographical distribution in Great Britain. Soil Use Manag 11(1):9-15. https://doi.org/10. 1111/j.1475-2743.1995.tb00488.x

Jenkins GJ, Murphy JM, Sexton DMH, Lowe JA, Jones P, \& Kilsby CG (2009) UK climate projections: briefing report. Met Office Hadley Centre, Exeter, UK Available from: http://ukclimateprojections. defra.gov.uk/images/stories/briefing_pdfs/UKCP09_Briefing.pdf

JNCC (n.d.) Retrieved September 17, 2018, from http://jncc.defra.gov. uk/page-6325

Le Quéré C, Andrew RM, Friedlingstein P, Sitch S, Hauck J, Pongratz J, Pickers PA, Korsbakken JI, Peters GP, Canadell JG, Arneth A, Arora VK, Barbero L, Bastos A, Bopp L, Chevallier F, Chini LP, Ciais P, Doney SC, Gkritzalis T, Goll DS, Harris I, Haverd V, Hoffman FM, Hoppema M, Houghton RA, Hurtt G, Ilyina T, Jain AK, Johannessen T, Jones CD, Kato E, Keeling RF, Goldewijk KK, Landschützer P, Lefèvre N, Lienert S, Liu Z, Lombardozzi D, Metzl N, Munro DR, Nabel JEMS, Nakaoka S, Neill C, Olsen A, Ono T, Patra P, Peregon A, Peters W, Peylin P, Pfeil B, Pierrot D, Poulter B, Rehder G, Resplandy L, Robertson E, Rocher M, Rödenbeck C, Schuster U, Schwinger J, Séférian R, Skjelvan I, Steinhoff T, Sutton A, Tans PP, Tian H, Tilbrook B, Tubiello FN, van der Laan-Luijkx IT, van der Werf GR, Viovy N, Walker AP, Wiltshire AJ, Wright R, Zaehle S, Zheng B (2018) Global carbon budget 2018. Earth Syst Sci Data 10:2141-2194. https://doi.org/10. 5194/essd-10-2141-2018

Li P, Holden J, Irvine B (2016) Prediction of blanket peat erosion across Great Britain under environmental change. Climatic Change 134(12):177-191. ISSN 0165-0009. https://doi.org/10.1007/s10584-015$1532-x$

Lindsay R, Charman DJ, Everingham F, O'Reilly RM, palmer M a, Rowell T a, Stroud D a (1988) The flow country: the peatlands of Caithness and Sutherland. Nature Conservancy Council, Peterborough Retrieved from http://roar.uel.ac.uk/1155/

Lindsay R (2010) Peatbogs and carbon: a critical synthesis to inform policy development in oceanic peat bog conservation and restoration in the context of climate change. Report to RSPB Scotland, Edinburgh

Lindsay R, Birnie R, Clough J (2014) Peatbog Ecosystems: Key Definitions IUCN UK Committee Peatland Programme briefing note No.1. Retrieved from http://www.iucn-ukpeatlandprogramme.org/sites/www.iucn-uk-peatlandprogramme. org/files/1 Definitions final - 5th November 2014.pdf

Met Office. (2018a). https://ukclimateprojections.metoffice.gov.uk. Retrieved September 18, 2018, from https://ukclimateprojections. metoffice.gov.uk

Met Office. (2018b). https://www.metoffice.gov.uk. Retrieved September 18, 2018, from https://www.metoffice.gov.uk
Nakicenovic N, Alcamo J, Davis G, de Vries B, Fenhann J, Gaffin S, Gregory K, Griibler A, Yong Jung T, Kram T, Lebre La Rovere E, Michaelis L, Mori S, Morita T, Pepper W, Pitcher H, Price L, Riahi K, Roehrl A, Rogner DZ (2000) Summary for Policymakers. In: Emission scenarios, vol 1. Cambridge University Press. https://doi. org/10.1017/CBO9781107415324.004

Pearsall W (1950) Mountains and moorlands. Collins, London

Pearsall W (1965) Mountains and Moorlands. Bloomsberry Books, Ed., London

Ratcliffe J, Payne RJ, Sloan T, Smith B, Waldron S, Mauquoy D, Newton A, Anderson AR, Henderson A, Andersen R (2018) Holocene carbon accumulation in the peatlands of northern Scotland. Mires and Peat. ISSN 1819-754X. https://doi.org/10.19189/MaP.2018.OMB. 347

Robertson RA (1971) Nature and extent of Scottish peatlands. Acta Agralia Fennica 123:233-241

Scotland FC (2018) No title. Retrieved October 2, 2018, from https:// scotland.forestry.gov.uk/news/peatland-restoration

Scottish Government. (2018a). Climate change plan: the third report on proposals and policies 2018-2032. Edinburgh

Scottish Government. (2018b). Scottish greenhouse gas emissions 2016. Edinburgh

SNH. (2016) Carbon and Peatland 2016 map. Retrieved September 17, 2018, from http://soils.environment.gov.scot/maps/thematic-maps/ carbon-and-peatland-2016-map/

The Land Cover of Scotland 1988. Aberdeen

Turetsky MR, Benscoter B, Page S, Rein G, Van Der Werf GR, Watts A (2015) Global vulnerability of peatlands to fire and carbon loss. Nat Geosci 8(1):11-14. https://doi.org/10.1038/NGEO2325

Waddington JM, Strack M, Greenwood MJ (2010) Toward restoring the net carbon sink function of degraded peatlands: short-term response in $\mathrm{CO}_{2}$ exchange to ecosystem-scale restoration. J Geophys Res 115(G1):G01008. https://doi.org/10.1029/2009JG001090

Worrall F, Evans MG, Bonn A, Reed MS, Chapman D, Holden J (2009) Can carbon offsetting pay for upland ecological restoration? Sci Total Environ 408(1):26-36. https://doi.org/10.1016/j.scitotenv. 2009.09.022

Worrall F, Chapman P, Holden J, Evans C, Artz R, Smith P, \& Grayson R (2011) A review of current evidence on carbon fluxes and greenhouse gas emissions from UK peatlands. Peterborough, UK, Joint Nature Conservation Committee, pp. 91 (JNCC Report No. 442). http://jncc.defra.gov.uk/pdf/jncc442_webFinal.pdf

Yu Z, Beilman DW, Jones MC (2009) Sensitivity of northern peatland carbon dynamics to Holocene climate change. Carbon cycling in northern peatlands 184:55-69. https://doi.org/10.1029/ 2008GM000822

Publisher's note Springer Nature remains neutral with regard to jurisdictional claims in published maps and institutional affiliations. 